\title{
Działania publiczne wobec uwarunkowań historyczno-kulturowych
}

\begin{abstract}
Streszczenie
Autor analizuje czynniki społeczno-kulturowe określające wewnętrzną strukturę działania zbiorowego. Uwarunkowana jest ona: zdolnością do zawierania umów, przewidywalnością zachowań oraz predyspozycją do okazywania zaufania. Opisuje także przyczyny ograniczające czy utrudniające realizację powyższych wymiarów. Wynika to ze specyfiki stosunków w polskim społeczeństwie, które jest zdominowane przez mikrogrupy, co oznacza, że tylko w ich obrębie - a nie w szerszej wspólnocie - rozwijają się relacje umożliwiające honorowanie umów czy okazywanie zaufania.

Ponadto, w opracowaniu wskazano, że zdolność do zbiorowego działania w społeczeństwie polskim istotnie ogranicza niepełne przyswojenie kultury kartezjańskiej. Pociąga to za sobą wiele konsekwencji - niższą zdolność do analizy celów działania, ich racjonalizowania itp. W społeczeństwach „kartezjańskich” (realizujących kartezjański ideał kulturowy) ich członkom łatwiej jest podejmować działania zbiorowe. Są lepiej przystosowane do demokracji i tym samym do współdziałania zbiorowego. Widoczny jest w nich wysoki poziom samoorganizacji, bardzo duży zakres wolności zachowań, głoszenia dowolnych poglądów, zakładania dowolnych organizacji. Nie potrzebują odgórnych dyrektyw i odgórnej koordynacji, gdy trzeba coś wspólnie przeprowadzić.
\end{abstract}

Słowa kluczowe: działania zbiorowe, kartezjanizm, epistemologia, racjonalizm, kolektywizm, socjologia wiedzy

\section{Public action in the face of historical and cultural determinants}

\begin{abstract}
The author analyses the socio-cultural determinants which influence the internal structure of collective action. It is determined by: the ability to fulfill contracts, the predictability of behaviour and showing trust to others. The author goes on to describe the factors that limit them as a result of the specificity of social relations in the Polish society, which
\end{abstract}


are dominated by the network of micro-groups and it means that only within them - not within the wider society - one can see social relations, in which contracts tend to be fulfilled and trust guaranteed.

At the same time, the author indicates that the Polish society's capacity for collective action seems to be limited as a result of the fact that the Cartesian culture has not been fully adopted. There are many ramifications of that including a lower potential to analyse the goals of collective actions and making them more rational. In the Cartesian type of societies, their members are more favourably inclined to act together. They are more favourably adapted towards democracy, collective action and one can see a higher level of self-organisation, a wider range of personal freedom, as well as the setting up of associations. There is no need to impose top-down directives and top-down coordination when collective action must be taken.

Keywords: collective action, Cartesianism, epistemology, rationalism, collectivism, sociology of knowledge

Opracowanie przedstawia uwarunkowania istotne dla kształtowania się charakteru działania zbiorowego i polityki publicznej państwa. Prezentowana poniżej teza głosi, iż w społeczeństwie, którego strukturalizacja opiera się na dominacji mikrogrup rodzinno-koleżeńskich panują niezbyt sprzyjające warunki dla działań zbiorowych (publicznych), w tym dla funkcjonowania instytucji demokratycznych, jak i dla rozwoju gospodarczego. Otóż mikrogrupy nie tworzą warunków do odpowiedniego poziomu samoorganizacji w skali ponadrodzinnej (całego społeczeństwa) czy warunków do łączenia kapitałów i tworzenia wieloskładnikowych przedsięwzięć. Ograniczają także oddziaływanie czynników, które warunkują dojrzałe działanie zbiorowe:

- zdolność do zawierania umów,

- przewidywalność zachowań w szerszym społeczeństwie,

- zdolność do wytwarzania zaufania.

Ograniczona zdolność do zawierania trwałych i wiarygodnych wzajemnych umów wynika $\mathrm{z}$ tego, że absolutny priorytet mają zobowiązania wobec własnej grupy rodzinno-koleżeńskiej, co oznacza, że jeżeli ktoś zawiera umowę z kimś spoza swojej grupy rodzinno-koleżeńskiej, to może nie uznawać jej do końca za wiążącą. Co więcej, jeśli umowa zakłada zrobienie czegoś istotnego dla kogoś spoza takiej grupy, to jej członkowie mogą to uznać za coś wręcz niemoralnego (najpierw liczą się ludzie najbliżsi).

Ograniczona wydaje się także przewidywalność zachowań. Jest bowiem tak, że im silniejsza solidarność rodzinno-koleżeńska, tym mniejsza przewidywalność zachowań w szerzej pojmowanym społeczeństwie (w relacjach odpersonalizowanych, czyli w relacjach między nieznajomymi). Z kolei poziom zaufania musi obniżać się 
wobec obecnego u nas partykularyzmu etycznego (skłonność do stosowania odrębnych kryteriów oceny ludzi z własnej grupy i spoza niej). Im jest on większy, tym bardziej widoczny jest niższy poziom zaufania. Obniżaniu ulegają także szanse na respektowanie umów i długofalowe współdziałanie zbiorowe.

A zatem, nadmiernie silne więzi rodzinne i nadmierny nacisk na bliskość emocjonalną mogą wpływać na kształt życia zbiorowego, w tym rodzić chaos życia codziennego. Może ulegać redukcji skłonność do okazywania zaufania w szerszej skali, co jest racjonalnie uzasadnione niskim prawdopodobieństwem dotrzymania zobowiązań.

Dalsze rozważania poświęcone są analizie związku między opisanymi wcześniej tendencjami strukturalizacji społecznej a postawami społeczno-politycznymi, tzn. takimi, które odzwierciedlają stosunek jednostek do instytucji, idei i działań związanych ze sprawowaniem władzy w społeczeństwie.

Kluczowe założenie leżące u źródeł dalszych analiz nawiązuje do metodologii strukturalnej. Na jej gruncie postawy i zachowania społeczne traktowane są jako efekt określonego, specyficznego usytuowania jednostek w strukturze społecznej, która w omawianym przypadku oznacza sposób, w jaki powiązani są ze sobą członkowie społeczeństwa oraz charakter tych więzi. Na przykład w grupach o przewadze więzi rzeczowej (bezosobowej) wpływ grupy na zachowania przebiega inaczej niż w grupach o więzi emocjonalnej.

W toku dalszej analizy poszukiwane będą odpowiedniości między strukturą grupy rodzinno-koleżeńskiej a postawami społecznymi. W szczególności skupimy się na tych postawach, które zdaniem autora mają kluczowe znaczenie dla funkcjonowania sfery działań zbiorowych.

\section{Świat mikrogrup}

W Polsce mamy do czynienia ze specyficzną strukturalizacją społeczeństwa. Jej odzwierciedleniem jest sieć mikrogrup. W ich obrębie jednostki zaspokajają niemal wszystkie swoje potrzeby egzystencjalne. Z obserwacji autora, przeprowadzonych w związku z pisaniem monografii Pułtuska, wynika, że grupy te zaspokajały cały kompleks potrzeb jednostek - od konsumpcji, po potrzeby ekspresji politycznej. $\mathrm{Z}$ wielu badań płyną podobne wnioski ${ }^{1}$.

1 J. Koralewicz, E. Wnuk-Lipiński, Życie rodzinne, towarzyskie i publiczne. Wartości i deprywacje, w: Nierówności i upośledzenia w świadomości społecznej, red. E. Wnuk-Lipiński, Archiwum PTS; J. Koralewicz, E. Wnuk-Lipiński, Wizje społeczeństwa w świadomości zbiorowej, „Studia Socjologiczne” 1987, nr 2; J. Szmatka, Źródła i konsekwencje napięć w małych grupach, „Studia Socjologiczne” 1988, nr 3, s. 18-43. 
Taką mikrogrupę stanowi rodzina uzupełniona o przyjaciół i znajomych ${ }^{2}$. Jest to widoczne szczególnie wyraźnie w małym mieście. Istnieje tam na ogół bardzo klarowny system polegający na tym, że wokół rodziny nuklearnej koncentruje się „,układ przyjaźni", w skład którego wchodzą ludzie odgrywający role zawodowe ważne dla funkcjonowania danej rodziny, tacy jak lekarz, nauczyciel czy urzędnik. Ten „układ przyjaźni” ma zazwyczaj charakter dość trwały, a więź rzeczowa jest bardzo silnie wzmocniona więzią emocjonalną i odwrotnie.

Znaczenie grup rodzinno-koleżeńskich dla zachowań społecznych jest relatywnie większe w społeczeństwach o niskim poziomie indywidualizmu i silnym nastawieniu na zaspokojenie potrzeb afiliacyjnych (potrzeb przynależności). W takich społeczeństwach instytucje publiczne są traktowane jako obce, a w kulturze dominuje kult rodziny (rodu) i niechęć do ponadrodzinnych form współdziałania (partie i inne zrzeszenia obywatelskie).

Grupy rodzinno-koleżeńskie uzyskały szczególnie duże znaczenie w epoce późnych lat Polski Ludowej, kiedy miały miejsce znaczne niedobory na rynku. Dlatego wzrosło znaczenie nieformalnej wymiany usług i towarów. Grupy te obsługiwały procesy zaspokajania potrzeb bytowych i afiliacyjnych oraz dawały wiedzę czy zapewniały bezpieczną ekspresję postaw kontestacji politycznej.

Po zmianie ustroju grupy rodzinno-koleżeńskie uległy pewnym modyfikacjom. Tym razem mniejsze znaczenie zyskała wymiana różnego typu dóbr i usług. Zmniejszyła się liczebność uczestników grup, a także ich spoistość w następstwie procesów indywidualizacji, jakim zaczęło podlegać polskie społeczeństwo po $1990 \mathrm{r}$. Trwałość rodzin nuklearnych w coraz większym stopniu zależy od spełnienia indywidualnych aspiracji uczestników małżeństwa. A ponieważ nie zawsze tak się dzieje, po zmianie ustrojowej wydatnie wzrosła liczba rozwodów ${ }^{3}$. Pewnemu rozluźnieniu uległy więzi międzypokoleniowe wśród kobiet. I tak np. $\mathrm{z}$ wielu rozmów z kobietami przeprowadzonych przez A. Graff ${ }^{4}$ wynika, że obecne babcie są coraz mniej skłonne do świadczenia bezpłatnej pracy w gospodarstwach domowych swoich dzieci. Wydatnemu zmniejszeniu czy nawet zanikowi uległ ponadklasowy charakter uczestnictwa w grupach rodzinno-koleżeńskich. Natomiast bez zmian pozostał prymat więzi emocjonalnej i nacisk na jednolitość postaw oraz absolutny prymat więzi grupowej nad wszelkimi innymi więziami i zobowiązaniami.

2 Zob. S. Nowak, Społeczeństwo polskie drugiej połowy lat osiemdziesiatych, „Studia Socjologiczne” 1988, nr 1; E. Tarkowska, Mała grupa w nieprzyjaznym środowisku, „Studia Socjologiczne” 1988, nr 4.

3 W 1990 r. na tysiąc zawartych małżeństw odnotowano 129,6 rozwodu, w 2000 r. - 202,6, a w 2011 r. - 312,8, GUS 2012, s. 240.

4 A. Graff, Szoruj babciu, „Wysokie Obcasy”, 16.08.2014, s. 4. 


\section{Ideały mikrogrup}

Ktoś może powiedzieć, że nic dziwnego w powyższych spostrzeżeniach, ponieważ w każdym społeczeństwie są przecież rodziny i przyjaciele. Na czym polega więc polska specyfika? Otóż polega ona na tym, że Polacy identyfikują się z owymi grupami znacznie silniej niż ze wszystkimi innymi i dlatego grupy te wywierają największy wpływ na zachowania i działania publiczne.

Specyfiką mikrogrup jest to, że ich członków łączy przede wszystkim więź emocjonalna. To z kolei sprawia, że ideałem staje się - tak jak w rodzinie - pełna zgodność i podobieństwo pod względem postaw, poglądów i stylów życia. Wobec tego grupy te cechuje duży poziom integracji i swoista „zazdrość”, jeśli chodzi o kontakty i uczestnictwo we współdziałaniu z ludźmi spoza danej grupy.

Występowanie silnej więzi emocjonalnej w mikrogrupach ma swoje konsekwencje. Otóż prowadzi często do tego, że członkowie mikrogrup tylko w swoim gronie zachowują się w sposób przewidywalny. Natomiast przewidywalność w sytuacjach bezosobowych jest ograniczona. Czują się źle, gdy muszą współdziałać z ludźmi, których osobiście nie znają, z którymi nie łączy ich więź emocjonalna i którzy różnią się od nich, choćby tylko trochę, postawami albo stylem życia. Powstaje skłonność do traktowania innych grup jako obcych i wrogich. To samo może dotyczyć także instytucji opartych na bezosobowych regułach, a także takich faktów jak rynek, przetarg, konkurs na stanowisko, przepis kodeksu administracyjnego itp. Natomiast kontakty z członkami innych grup, uznawanych często za obce i wrogie, mogą być traktowane nawet w kategoriach „zdrady”.

\section{Działania zbiorowe w modelu społeczeństwa indywidualistycznego i kolektywistycznego}

Wobec powyższego, można poczynić rozróżnienie między modelem społeczeństwa indywidualistycznego a modelem społeczeństwa kolektywizmu koleżeńsko-rodzinnego. W tym pierwszym możemy odnaleźć więcej zbiorowego współdziałania. Jest bowiem tak, że im większy indywidualizm, tym powstaje mniejsze prawdopodobieństwo, iż dana osoba przełoży nowe oczekiwania grupy nad wcześniejsze własne zobowiązania. Efektem są wyższy poziom respektowania umów i większy zakres współdziałania.

Zdarza się, że obserwatorzy polskiej sfery publicznej odnotowują niski poziom współdziałania, a obwiniają za to indywidualizm Polaków. W rzeczywistości jest to błędne wyjaśnienie. Otóż słabe współdziałanie jest następstwem chaosu życia 
codziennego, który wynika z niskiej skłonności do dotrzymywania umów, konformizmu wobec własnej grupy i nieufności wobec wszystkiego, co nią nie jest.

Przykładem słabej aktywności zbiorowej u nas jest choćby niski poziom przynależności do zrzeszeń miejskich. Ale nie wynika to $\mathrm{z}$ indywidualizmu, ale z logiki funkcjonowania grupy rodzinnej. Związuje ona swoich członków więzią zarówno rzeczową, jak i nakładającą się na nią więzią emocjonalną. Członkowie grup rodzinno-koleżeńskich uznają funkcjonowanie w zrzeszeniach jako zagrożenie dla swojej spoistości. Ponadto członkowie tego rodzaju mikrogrup przyzwyczajeni są do zaspokajania potrzeb materialnych w koincydencji z emocjonalnymi kontaktami. Natomiast w zrzeszeniu pojętym jako bezosobowy organizm zaistnienie bliskiej więzi emocjonalnej jest raczej niemożliwe, dlatego że skupia ono zbyt dużo ludzi. W tej sytuacji człowiek czuje się zagubiony, a jego integracja psychiczna jest poważnie zagrożona. Dotyczy to wszystkich zrzeszeń większych niż grupa rodzinna, wymagających osobistego kontaktowania się z innymi uczestnikami. Inna sytuacja ma miejsce $w$ wypadku integracji z narodem. Ta, wbrew pierwszej intuicji, jest jednak zgodna z dynamiką mikrogrup. Ma bowiem charakter emocjonalny, na co dzień jest niezobowiązująca i niezagrażająca spoistości grupy koleżeńsko-rodzinnej.

W modelu społeczeństwa kolektywizmu koleżeńsko-rodzinnego widzimy skłonność do odtwarzania relacji rodzinnych i koleżeńskich we wszystkich innych sferach życia. Rodzi to wiele następstw. W sferze polityki skutkuje niskim poziomem partyjnego uczestnictwa oraz zdominowaniem samorządów i lokalnych struktur partyjnych przez rodziny. W gospodarce przedsiębiorcy za ideał uważają osobiste kierowanie firmą rodzinną (widać to nawet $\mathrm{w}$ wielkich, złożonych konglomeratach firm). W tej sytuacji łączenie kapitałów jest w zasadzie niewyobrażalne, podobnie jak dopuszczenie do zarządzania kogoś spoza rodziny.

Dochodzi także do personifikacji instytucji publicznych. W powszechnej opinii rządzą nimi kliki osób na ogół znanych z nazwiska, pochodzenia, kariery itp. W efekcie wrogość ogniskuje się na innych grupach typu rodzinno-koleżeńskiego. Wrogość ta dotyczy nie tylko stosunku do grup „rządzących” (choć w tym wypadku jest najsilniejsza), lecz także wszelkich innych, z którymi członkowie danej grupy wchodzą w jakieś relacje. Poczucie zagrożenia jest wszechogarniające i - co charakterystyczne - każda z tych grup jest przekonana, że to jej członkowie zostali oszukani, pokrzywdzeni, są dyskryminowani itp. Niechęć ta wynika z jednej strony $\mathrm{z}$ uświadomienia sprzecznych interesów, z drugiej zaś - ze świadomości różnic, tzn. odnotowania, że inni mają czegoś więcej. Stąd mikrogrupę integruje uczestnictwo w korzyściach (konsumpcji). Wszelkie inne aspiracje wykraczające poza tę problematykę są traktowane jako zbędne bądź zwalczane, jeżeli prowadzą do wyróżniania się poszczególnych osób lub, co gorsza, do naruszania równości. Na przykład z badań 
nad motywacjami pracowniczymi wynika, że dla większości najważniejsze są dobre stosunki ze współpracownikami i kierownictwem oraz pewność pracy (60-70\%). Natomiast satysfakcja intelektualna i doskonalenie (zrobić coś lepiej niż inni) mają zdecydowanie mniejsze znaczenie (do 15\%).

\section{Postawy wobec innych obywateli. Zakres solidarności}

Dominacja mikrogrup ma dalszy wpływ na charakter działania zbiorowego. Ma to związek z preferowanym w nich zakresem solidarności. Otóż grupy rodzinno-koleżeńskie dość wyraźnie forsują partykularne normy solidarności kosztem norm uniwersalnych. Te pierwsze standardy skłaniają do ocen jednostki, jej statusu społecznego wyłącznie na podstawie kryteriów, które potencjalnie może spełnić każdy członek danego społeczeństwa, takich jak praca, kwalifikacje itp. Z kolei kultywowanie norm partykularnych skłania do wykluczania niektórych jednostek - np. Żydów czy Murzynów ${ }^{6}$ - z możliwości uzyskania najwyższych ocen, na przykład prestiżu (ponieważ nie przynależą do grupy).

W związku z powyższym współdziałanie członków różnych mikrogrup jest niezwykle trudne do zainicjowania. Dochodzi do atomizacji społecznej, ale w postaci izolowania nie jednostek, ale poszczególnych grup. Konsekwencje tego stanu rzeczy prowadzą do wyizolowania społecznego ludzi w sferze życia publicznego, tzn. we wszystkich tych sferach życia, w których jednostki muszą wystąpić w innych rolach niż te, które wiążą się z ich członkostwem w grupie koleżeńsko-rodzinnej. Wszelkie takie sytuacje, w których nie można natychmiast odwołać się do opinii mikrogrupy, budzą lęk i się ich unika.

\section{Racjonalna analiza i emocje - wpływ na działania zbiorowe}

Działanie zbiorowe jest silnie uwarunkowane sposobem cyrkulacji informacji. W grupach koleżeńsko-rodzinnych wymiana informacji służy przede wszystkim utwierdzeniu więzi społecznej. $\mathrm{Z}$ tego powodu rozmowy mają często

5 Zob. J. Hryniewicz, Stosunki w pracy w polskich organizacjach, Wydawnictwo Naukowe Scholar, Warszawa 2007.

6 T. Parsons, The System of Modern Societies, Englewood Cliffs, Prentice Hall, New Jersey 1971, s. 91 i nast. 
konwencjonalno-rytualny charakter wymiany deklaracji o identycznych interesach i poglądach na daną sprawę.

Wymiana informacji nie ma zatem wydźwięku dyskursywnego, zmierzającego do rozwiązania danego problemu, m.in. dlatego, że tego typu dialog nieuchronnie musiałby wprowadzić propozycje nowych, odmiennych punktów widzenia. Nawet próby przekazania informacji mówiących o tym, że inni mają odmienny pogląd, są traktowane jako rażące wystąpienie przeciwko solidarności grupowej.

Jest to zjawisko typowe dla grup, w których więź emocjonalna odgrywa rolę podstawową. W efekcie utrwalają się antyintelektualne orientacje osobowościowe, wynikające z niechęci do podejmowania jakiegokolwiek bardziej intensywnego i trwałego wysiłku umysłowego. Wyjaśnienia szerszych problemów sprowadzane są do gotowych, jednorodnych oraz emocjonalnie podbudowanych formuł. Jak się wydaje, najgroźniejszą konsekwencją tego stanu rzeczy jest intelektualna niemożność zaakceptowania wielości przyczyn różnych globalnych wydarzeń społeczno-politycznych. Przyzwyczajenie do oceny życia codziennego w kategoriach rodzinnych powoduje, że również w życiu publicznym dąży się do znalezienia jednej przyczyny „wszystkiego”.

\section{Wrogie otoczenie}

Na zdolność do działania publicznego ma także wpływ to, że mikrogrupom towarzyszy trwałe przekonanie o funkcjonowaniu w zdecydowanie wrogim otoczeniu. Rodzi to u ich członków nieuchronne poczucie zagrożenia i wzmacnia postawy autorytarne. W szczególności wspomniany wcześniej antyintelektualizm jest powiązany z przekonaniem, że jeśli człowiek „wychyli się” z mikrogrupy, spotyka wrogów, co prowadzi do nabywania paranoidalnych postaw wobec rzeczywistości społecznej.

Z badań zrealizowanych w USA i Meksyku wynika, że trwałe poczucie alienacji, krzywdy, wrogości i manipulacji nieuchronnie wiedzie do patologii psychicznej, tzw. paranoi ${ }^{7}$. Nie chodzi, rzecz jasna, o przypadki kliniczne, ale o nastawienie wobec społeczeństwa i jego funkcjonowania. Dlatego staje się oczywiste to, że opisana poprzednio gotowość do poszukiwania pierwszej i jedynej przyczyny wszystkiego najczęściej przejawia się w konstruowaniu wyjaśnień rzeczywistości w kategoriach spisku małej grupy osób nastawionej na szkodzenie, najchętniej Żydów.

Przekonania i postawy paranoidalne stanowią istotny czynnik przeciwdziałający uczestnictwu członków mikrogrup w innych ugrupowaniach, np. w zrzeszeniach

7 Zob. J. Mirowsky, C.E. Ross, Paranoia and the structure of powerlessness, "American Sociological Review" 1983, Vol. 48, No. 2. 
miejskich, uczestnictwo takie jest bowiem nieracjonalne z powodu poczucia całkowitej manipulacji, której nie sposób się przeciwstawić. „Izolacja i atomizacja społeczna są w badanej populacji raczej wynikiem psychologicznych potrzeb mieszkańców niż efektem świadomej polityki władz". Na poziomie ogólnokrajowym preferowane będą strategie inkluzyjne, podkreślające solidarność typu klasowego lub narodowego.

\section{Działania zbiorowe wobec kartezjańskiego ideału kulturowego}

Działania zbiorowe (współdziałanie zbiorowe) zyskały wiele potencjału w efekcie upowszechnienia się na świecie kartezjanizmu czy, innymi słowy, kartezjańskiego ideału poznawczego. Odegrał on decydującą rolę w ugruntowaniu myśli demokratycznej. Umożliwił zaistnienie demokratycznych form współdziałania ludzi wolnych, opartych na dobrowolnej umowie. W krajach zachodnich umożliwił przejście od dominacji mikrogrup i kolektywizmu do poszukiwania relacji w szerszym społeczeństwie.

Kartezjusz wytworzył model racjonalnego myślenia. Umożliwił on odmienne niż do tej pory postrzeganie relacji rodzina versus nie-rodzina. Segmentacja rzeczywistości społecznej na mniejsze lub większe całości pozwoliła na znajdowanie takich dziedzin, w których interesy rodziny własnej były niesprzeczne z interesami innej rodziny lub rodzin. Znajdowanie takich drobnych nawet obszarów zbieżności ułatwiało zdefiniowanie wspólnego interesu. Zjawisko to ulegało pogłębieniu, jeżeli towarzyszyła mu kartezjańska umiejętność zewnętrznego spojrzenia na grupę własną i zdanie sobie sprawy z odmienności pozycji w grupie oraz specyfiki pozycji własnej na tle innych. Zapoczątkowało to indywidualizm poznawczy, a potem etyczny. Dopiero co zrodzone przekonanie o wspólnocie interesów ponadrodzinnych w sprawach drobnych było wstępem do zaistnienia kolejnego znaczącego zjawiska.

Konstatacja istnienia podobnego interesu musiała skłaniać do przekonania, że partner czy partnerzy są tak samo racjonalni jak my. Jeżeli tak, to mogę od niego/od nich oczekiwać takich samych zachowań jak moje, w dziedzinie objętej podobnym interesem. Są takie korzystne cele, których osiągnięcie wymaga współpracy. Jeżeli tak, to muszę wejść w umowę z inną osobą lub osobami i zobowiązać się do wykonania stosownych działań. Ponieważ zależy mi na realizacji celu, to mam wolę wywiązania się z umowy. Jeżeli partner ma takie same interesy, to również i on myśli podobnie. Mogę zatem oczekiwać, że do wywiązania się z umowy dołoży równie dużo starań jak ja.

8 J. Hryniewicz, Procesy aktywności publicznej w miejskich społecznościach lokalnych, „Studia Socjologiczne" 1990, nr 3-4, s. 61. 
Oznacza to, że zachowania innych ludzi w wąskim, na razie, fragmencie rzeczywistości są przewidywalne. A to z kolei znaczy, że można mieć do nich zaufanie. Zaufanie wzajemne wynika tu ze wspólnie podzielanego przeświadczenia, że można z ludźmi współpracować, ponieważ prawdopodobieństwo niedotrzymania umowy przez partnera jest mniejsze niż moje dążenie do wspólnego sukcesu.

W ten sposób kartezjańskie zasady poznawcze sprzyjały przezwyciężaniu lęku przed współpracą ponadrodzinną, wzmacniały emancypację jednostki i przyczyniały się do upowszechnienia się indywidualizmu etycznego.

Uwagi te nie wyczerpują wkładu racjonalności kartezjańskiej w inicjowanie form współdziałania zbiorowego. Aby mogła zaistnieć współpraca zbiorowa, trzeba wcześniej przedyskutować zgłoszone propozycje i uzgodnić wspólne cele. W trakcie realizacji takich ustaleń podstawową sprawą jest zdefiniowanie wspólnych kryteriów oceny prawdy, czyli tego, kto ma rację, a kto nie.

Kartezjański racjonalizm analityczny stał się specyficzny dla europejskiego kręgu kulturowego. Pobudza on do analizy społecznej, czyli analizy sądów o rzeczywistości w kategoriach prawdy albo fałszu. Jego specyfiką jest także:

- wyodrębnienie zjawisk o dużej społecznej doniosłości, takich jak władza, i ich analiza jako zjawisk niesakralnych,

- dystans badacza do otaczającej rzeczywistości (przedmiotu badania),

- krytyczny ogląd całości skłaniający do stawiania pytań, czy to, co nas otacza, jest dobre czy złe,

- poszukiwanie nowych, lepszych, form życia społecznego (owocowało m.in. utopiami, rewolucjami, ale i powstaniem instytucji demokratycznych).

Kartezjanizm oznaczał także laicyzację procesu poznawczego polegającą na oddzieleniu zamysłów boskich od stosowanego kryterium prawdy. Orzekanie o prawdzie albo fałszu stało się wyłączną domeną umysłu ludzkiego, stosującego powtarzalne i powszechnie znane sposoby dochodzenia do prawdy. Było to niezwykle ważne dla uporządkowania zasad współpracy zbiorowej. Przekonanie o obowiązku realizacji zamysłu boskiego wobec spraw ziemskich jest szczególnie narażone na działanie nieprzewidywalne i chaotyczne, także $\mathrm{w}$ warunkach ugruntowania się indywidualizmu. Wynika to stąd, że zamysł boski bywa odkrywany stopniowo i nie wiadomo, kiedy zostanie danej osobie objawiony. Dlatego dzisiejsza umowa wcale nie jest ostateczna, ponieważ jutro może nastąpić iluminacja i wszystko może się zmienić. Poddanie procesu stawiania celów i zawierania umów kontroli rozumu uprawdopodobniło to, że ludzie posługujący się taką samą logiką dostrzegą podobne cele i podobnie będą je wartościować. Umowy takie można bez obawy poddać nadzorowi osób trzecich, również posługujących się zbliżoną logiką. Sprzyja to przewidywalności zachowań i stabilności umów o współpracę zbiorową. 


\section{Myślenie racjonalne versus myślenie potoczne}

Kartezjańskie myślenie racjonalne zapobiega chaosowi, specyficznemu dla myślenia potocznego (spontanicznego). W myśleniu spontanicznym kryteria prawdy są płynne i rację może mieć zarówno ten, kto głośniej mówi, jak i ten, kto lepiej trafi do emocji słuchaczy albo ten, kto argumentuje górnolotnie czy kwieciście. Jednakże takie uzależnienie przekonania o słuszności od osobowości i nastroju sprawia, że interesy są realizowane przypadkowo i wiele osób nie ma szans na ich realizację. $\mathrm{W}$ efekcie chęć uczestnictwa w działalności zbiorowej jest bardzo mała.

Myślenie racjonalne zawiera relatywnie trwałe kryteria prawdy i utrwalone zasady wnioskowania. Ich upowszechnienie sprawia, że posiadanie racji czy słuszności jest efektem użycia argumentów powiązanych w określony sposób. Niezwykle pomocne w dziele usprawniania współdziałania zbiorowego było upowszechnienie zasad logiki formalnej, a zwłaszcza tego jej działu, który nazywa się rachunkiem zdań. Jest to nauka, która objawia zasady uznawania za prawdziwe lub fałszywe zdań złożonych z dwu stwierdzeń połączonych spójnikiem, np. „lub”, „i”, ,jeżeli, to.... Prawdziwość lub fałszywość zdania złożonego zależy od prawdziwości lub fałszywości stwierdzeń cząstkowych i sposobu ich połączenia - rodzaju spójnika. Dla przykładu, połączenie stwierdzeń za pomocą spójnika „i” (koniunkcja) sprawia, że zdanie jest fałszywe, jeżeli tylko jedno ze stwierdzeń jest fałszywe. Z kolei spójnik „lub” powoduje, że aby zdanie było prawdziwe, wystarczy, że tylko jedno stwierdzenie będzie prawdziwe. Na początku XX w. za sprawą Brewera pojawił się nurt konstruktywizmu logicznego, który stanowił połączenie logiki formalnej z wnioskowaniem indukcyjnym ${ }^{9}$.

Miało to bardzo duże znaczenie dla rozwoju metod statystycznych w naukach społecznych i wypracowania zasad poszukiwania związków przyczynowych na podstawie rachunku probabilistycznego. Opisane wyżej zasady logiki formalnej są uniwersalne, co oznacza, że prawdziwość lub fałszywość zdań nie zależy od konkretnej treści, ale od sposobu ich połączenia. Na przykład: „Jan jest wyższy od Andrzeja, a Andrzej od Jacka, zatem Jan jest wyższy od Jacka”. Zdanie tego typu jest prawdziwe niezależnie od tego, czy mówi o wzroście, wadze czy czymkolwiek innym, co da się porównać. Jeżeli np. po słowie „zatem” zawrzemy informację, że Jacek jest wyższy od Jana, to takie zdanie i inne mu podobne będą zawsze fałszywe ${ }^{10}$.

\footnotetext{
9 Zob. M. Porębska, W. Suchoń, Elementarny wykład logiki formalnej z ćwiczeniami komputerowymi, Universitas, Kraków 1999, s. 35-72.

10 Zob. J. Wehler, Zarys racjonalnego obrazu świata, Oficyna Naukowa, Warszawa 1998, s. 51 i nast.
} 
Jeżeli uwagi powyższe potraktujemy jako metaforę ewolucji racjonalnego myślenia „od Kartezjusza do rachunku zdań”, to nie sposób nie zauważyć, że mamy tu do czynienia ze stałym eliminowaniem spontanicznego myślenia i trwałą tendencją do opanowania chaosu intelektualnego. Ten ostatni proces odbywa się w drodze podporządkowania procesu postrzegania małej liczbie powtarzalnych i dających się upowszechnić reguł. Dla działalności zbiorowej ma to dość duże znaczenie, ponieważ to, czy ktoś ma rację, czy nie, może być ocenione za pomocą kryteriów logicznych znanych (potencjalnie) każdemu uczestnikowi procesu ustalania celów współdziałania. Jeżeli te oczekiwania są spełnione, to możemy mówić o modelu idealnym racjonalnego ustalania celów współdziałania zbiorowego. Model opisuje sytuację, w której każdy uczestnik współdziałania ma równe szanse w procesie tworzenia celu wspólnego, czyli takie same jak inni uczestnicy perspektywy tego, czy i w jakim stopniu jego interesy zostaną uwzględnione. Równe szanse wynikają stąd, że posiadanie racji jest funkcją poprawnego zastosowania zasad logiki do argumentacji, a zasady te są każdemu znane i każdy może je zastosować do argumentacji własnej. W takiej sytuacji liczba osób potencjalnie skrzywdzonych i niezadowolonych z braku możliwości realizacji interesów będzie relatywnie najmniejsza. Tym samym spełnienie opisanych wyżej warunków gwarantuje, że liczba osób skłonnych do współdziałania zbiorowego będzie relatywnie największa.

\section{Kartezjański ideał kulturowy a współdziałanie zbiorowe}

Jak wyżej zaznaczyłem, aktywności pozarodzinnej nie sprzyja silna identyfikacja jednostek $\mathrm{z}$ rodziną ${ }^{11}$ - była to moja obserwacja $\mathrm{z}$ końca lat 80 . XX w. wynikająca $\mathrm{z}$ badania małych miast. Podobne stanowisko zajmuje $\mathrm{w}$ tej sprawie Fukuyama ${ }^{12}$, który porównując społeczeństwo chińskie i japońskie stwierdza, że w Japonii więzy rodzinne są słabsze niż w Chinach i dlatego w Japonii jest więcej różnego typu stowarzyszeń ponadrodzinnych. Po głębszym zastanowieniu można jednak dostrzec, że teza ta nie grzeszy uniwersalizmem. Istnieją bowiem takie środowiska, w których więzy rodzinne są bardzo nietrwałe i identyfikacje z rodziną bardzo słabe, a stowarzyszeń ponadrodzinnych jest relatywnie mniej niż w środowiskach, gdzie rodziny są wyraźnie trwalsze.

${ }_{11}$ Zob. J. Hryniewicz, Procesy aktywności publicznej w miejskich społecznościach lokalnych, „Studia Socjologiczne" 1990, nr 3-4.

12 F. Fukuyama, Zaufanie: kapitat społeczny a droga do dobrobytu, Wydawnictwo Naukowe PWN, Warszawa, Wrocław 1997. 
Dobrym przykładem służą tu Afroamerykanie w USA, których rodziny są bardzo nietrwałe, a stowarzyszeń jest tam wyraźnie mniej niż wśród ludności środkowego zachodu Stanów Zjednoczonych, gdzie rodziny są bardziej trwałe i występują silniejsze identyfikacje z nimi. Oznacza to, że istnieją także inne czynniki, o większej sile sprawczej. Jednym z nich jest opisana wyżej kartezjańska racjonalność analityczna, która stanowi konieczny i zarazem wstępny czynnik współdziałania ludzi wolnych na podstawie umów. Brak tego typu kompetencji intelektualnych nie przekreśla oczywiście możliwości współdziałania zbiorowego, ale odbywa się ono w innych formach niż samoorganizacja i wolne umowy. Niskie umiejętności sprecyzowania celów współdziałania i ich poprawnego logicznie przedyskutowania sprawiają, że konieczna jest nadrzędna instytucja lub osoba, która odgórnie określi te cele i podział pracy. Próby samoorganizacji, bez pośrednictwa odgórnego rozjemcy, prowadzą do chaosu i rozpadu grupy.

Z dotychczasowych analiz wynika, że kultura grupowa wiąże się z samoorganizacją społeczną na kilka sposobów. Pierwszy wymiar to kolektywizm versus indywidualizm. Kultury nastawione kolektywistycznie są na ogół rodzinnocentryczne albo klanowe i dążą do ograniczenia aktywności pozarodzinnej na rzecz kultywowania więzi rodzinnej. Kultury nastawione indywidualistycznie zawierają mniej takich ograniczeń.

\section{Społeczeństwa kartezjańskie i niekartezjańskie}

W społeczeństwach kartezjańskich (realizujących kartezjański ideał kulturowy) ich członkom łatwiej jest podejmować działania zbiorowe. Są one lepiej przystosowane do demokracji i tym samym do współdziałania zbiorowego. Widoczny jest w nich wysoki poziom samoorganizacji, bardzo duży zakres wolności zachowań, głoszenia dowolnych poglądów, zakładania dowolnych organizacji. Nie potrzebują odgórnych dyrektyw i odgórnej koordynacji, gdy trzeba coś wspólnie przeprowadzić.

Typowe społeczeństwa kartezjańskie usytuowane są w Europie, Australii i obu Amerykach, natomiast słabsze oddziaływanie tego ideału kulturowego widzimy w Europie Wschodniej i Ameryce Łacińskiej. Społeczeństwa niekartezjańskie ulokowane są w Azji i Afryce.

Kartezjanizm służy działaniu zbiorowemu, ponieważ uregulował i zorganizował sposób myślenia wokół kilku zasad, dzięki czemu indywidualne produkty myślowe nie odbiegają od siebie nazbyt daleko. Mało zasad oznacza mały rozrzut efektów końcowych procesu myślenia. Członkowie takiego społeczeństwa łatwiej znajdują wspólny mianownik w poglądach i ideałach oraz łatwiej uzgodnić im wspólne 
działanie, wypracować dyscyplinę intelektualną służącą współdziałaniu zbiorowemu, co w ogóle jest warunkiem trwałej demokracji. Mało wolności intelektualnej, ale za to dużo behawioralnej.

Z kolei społeczeństwa niekartezjańskie relatywnie silniej dopuszczają spontaniczne myślenie i metafizykę codzienną, ale nie dają swoim uczestnikom tak dużo wolności behawioralnej, a raczej świadomie ją ograniczają. Nie może być inaczej, dlatego że spontaniczność intelektualna uniemożliwia znalezienie wspólnego mianownika między końcowymi efektami procesu myślenia o rzeczywistości. Utrudnia to samoorganizację i wymusza konieczność odgórnego nakazywania i kontrolowania współdziałania zbiorowego.

Na ogół jest tak, że społeczeństwa kolektywistyczne są zarazem bardziej metafizyczne, natomiast te indywidualistyczne częściej realizują kartezjański ideał kulturowy.

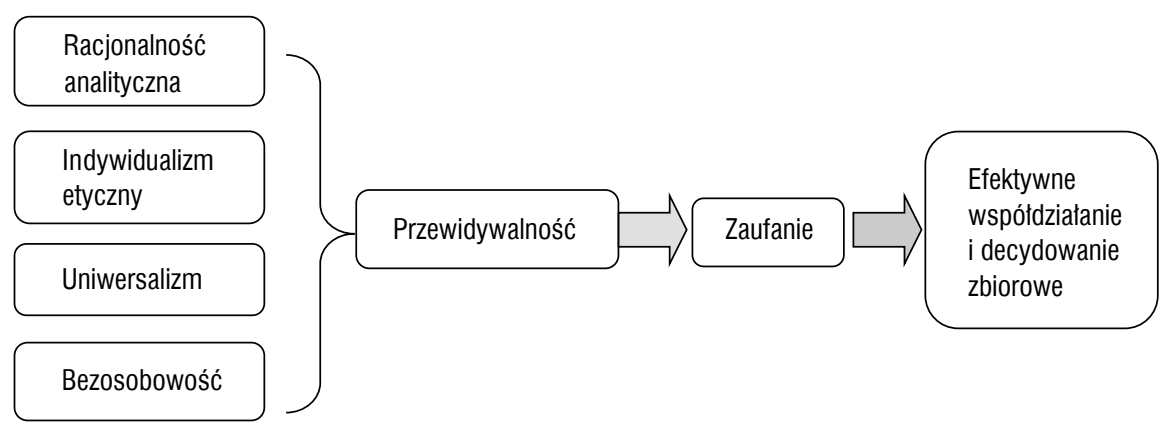

Rysunek 1. Schemat czynników sprawczych współdziałania zbiorowego

Źródło: opracowanie własne.

Podsumowując rozważania na tym etapie, można podkreślić stanowisko kartezjańskiego ideału kulturowego. Otóż w jego świetle współdziałanie zbiorowe $\mathrm{w}$ formie samoorganizacji staje się możliwe, gdy społeczeństwo ma zdolność do realizacji zasady:

- racjonalności analitycznej, która zakłada uznanie, że ocena słuszności argumentów opiera się na kilku powszechnie znanych zasadach logiki formalnej,

- indywidualizmu etycznego, który polega na przyznawaniu pierwszeństwa zobowiązaniom zawartym osobiście przed zobowiązaniami wynikającymi z przynależności grupowej, które nie istniały w momencie zawierania umowy, a które potencjalnie mogą się pojawić. Przeciwieństwem jest kolektywizm, w którym czyjeś zobowiązania wobec grupy dominują nad wszystkimi innymi umowami zawartymi przez tę osobę, 
- bezosobowości, która polega na umiejętności oddzielenia osobowości, psychiki i emocji od dyskutowanego problemu oraz na oddzieleniu cech osobowości partnerów od głoszonych przez nich poglądów. Dyskutuje się o treści zdań, a nie o cechach osobowości ich autorów. Posługiwanie się logicznymi argumentami, bezosobowość i indywidualizm etyczny sprzyjają przewidywalności zachowań wzajemnych, co z kolei zwiększa poczucie bezpieczeństwa,

- uniwersalizmu, który polega na usiłowaniu wyznaczenia, możliwie niewielu, powszechnie akceptowanych zasad ogólnych stanowiących punkt odniesienia w rozstrzyganiu sporów czy dyskusji. Racje przyznaje się poglądowi najlepiej przystającemu do zasady ogólnej. Uniwersalizm jest odwrotnością i dopełnieniem racjonalności analitycznej. Umożliwia scalanie wielu poglądów indywidualnych w jedną nadrzędną ideę. $W$ ten sposób sprzyja przewidywalności zachowań, a także ułatwia przystosowanie zbiorowości do współdziałania na bazie nowych interesów, poglądów, idei itp. Nowe interesy są dzielone na drobne części, znajdowane są nowe podobieństwa i ustalane są nowe zasady ogólne,

- przewidywalności i zaufania, które wiążą się z przekonaniem, że inni ludzie kierują się takimi samymi zasadami moralnymi jak nasze własne i są skłonni włożyć tyle samo starań i wysiłku w dotrzymanie zobowiązań czy w realizację uzgodnionego planu, ile my sami byśmy włożyli. Zaistnienie takiego przekonania wydatnie zmniejsza ryzyko kooperacji i sprzyja wzrostowi skłonności do wspólnego działania.

Ponadto, do udanego współdziałania trzeba udanego porozumiewania się co do celów wspólnych działań. Nie zawsze jednak jest tak, że do udanej kooperacji wystarcza precyzyjne operowanie nazwami przedmiotów, dokładne rozpoznanie rzeczywistości i sprawne posługiwanie się logiką. Dzieje się tak dlatego, że słowa nabierają znaczenia wtedy, gdy są odniesione do innych niezwerbalizowanych treści. Słowa nabierają znaczenia $\mathrm{w}$ następstwie ich połączenia z podświadomymi skojarzeniami i równie podświadomą wiedzą zbiorową. Zobaczmy, jak problem ten jest rozważany na gruncie filozofii społecznej. Jak pisze J. Habermas, zrozumienie intencji zależy nie tylko od powiązania słów z ich desygnatami. Pełne zrozumienie przekazu jest możliwe tylko wtedy, gdy partnerzy osadzają słowa w tak samo rozumianym kontekście znaczeniowym.

„Ta fundamentalna, stanowiąca ukryte podłoże wiedza, która musi milcząco dopełniać znajomość warunków akceptowalności językowo standaryzowanych wypowiedzi, aby słuchający mógł zrozumieć ich dosłowne znaczenie, odznacza się osobliwymi właściwościami: jest to wiedza niewyartykułowana explicite, której nie można przedstawić w skończonej liczbie zdań orzekających: jest to wiedza ustrukturowana holistycznie, której elementy nawzajem do siebie odsyłają: jest to wiedza, 
która o tyle jest w naszej dyspozycji, że nie możemy jej sobie na życzenie uświadomić oraz podać $\mathrm{w}$ wątpliwość. Jeżeli mimo wszystko filozofowie podejmują taką próbę, to owa wiedza objawia się w postaci zdroworozsądkowych pewników"13.

Rzadko się zdarza, aby filozoficzne dociekania znajdowały bezpośrednie praktyczne zastosowanie i to w dość odmiennym kontekście kulturowym. A tak jest w wypadku cytowanego tu fragmentu teorii działania komunikacyjnego. Oto bowiem japońscy badacze zarządzania japońskimi fabrykami stwierdzają, że „wiedza wyrażona w słowach i liczbach stanowi zaledwie wierzchołek góry lodowej (...) wiedza ukryta (...) jest trudna do sformalizowania i może być ujmowana w dwu wymiarach (...) technicznym i poznawczym - schematów, modeli mentalnych, przekonań i spostrzeżeń, zakorzenionych tak głęboko, że uznaje się je za oczywiste" ${ }^{\prime 4}$.

Jak widzimy, idee filozoficzne znajdują zastosowanie do analizy porozumiewania się ludzi w trakcie współdziałania gospodarczego. Badania filozoficzne mają zatem potencjał doskonalenia praktyki gospodarczej. Słowa opisujące cele, formy współdziałania i ich zakres są rozumiane tak samo tylko wtedy, gdy ludzie je wypowiadający dysponują taką samą podświadomą wiedzą zbiorową. Współdziałanie gospodarcze tylko wtedy jest w miarę płynne, gdy osadzone jest w tych samych archetypach, wartościach i symbolach kulturowych ${ }^{15}$, czyli wtedy, gdy jest realizowane przez ludzi tej samej kultury (wspólna kultura = wspólna wiedza ukryta).

\section{Kartezjanizm a osobowość}

Kartezjanizm kształtował myślenie i jego racjonalność, ale także całą strukturę osobowości. Dotychczasowe rozważania pokazywały, jak ukształtowała się i upowszechniła kartezjańska epistemologia i jak kształtuje ona struktury myślowe, ukierunkowuje sposób postrzegania i nie dopuszcza, aby postrzeganie i analiza otoczenia wykraczały poza ustalone ramy.

Właściwy kartezjańskiemu ideałowi kulturowemu rygoryzm intelektualny narzuca na umysł bardzo silne ograniczenia. Ogranicza ekspresję, odgórnie kawałkuje osobowość na rozum i psychikę, narzuca umysłowi określone ścieżki i zmusza do zaniechania innych. Dla niektórych osób ograniczenia te są nazbyt silne i mogą

${ }^{13}$ J. Habermas, Teoria działania komunikacyjnego, przeł. A.M. Kanowski, t. 1, Wydawnictwo Naukowe PWN, Warszawa 1999, s. 552.

${ }^{14}$ I. Nonaka, H. Takeuchi, Kreowanie wiedzy w organizacji: jak spótki japońskie dynamizuja procesy innowacyjne, Wydawnictwo Poltext, Warszawa 2000, s. 25.

${ }^{15}$ Należy zwrócić uwagę, że nie chodzi tu o proste uzgodnienia typu: „zamieć”, „przyniosę”, „zakręcę”, „wyłącz”, a o takie wydarzenia, jak ustalanie celów przedsiębiorstwa, jego wielkości, własności (czy ma być rodzinne czy ponadrodzinne), sposobu podziału zysku na konsumpcję i inwestycje itp. 
prowadzić do stanów chorobowych, takich jak wcześniej opisane symptomy paranoidalne lub jakiekolwiek inne.

Kartezjanizm otwiera nowe horyzonty, ale także rodzi zagrożenia. Już w latach 30. XX w. na gruncie socjologii wiedzy sformułowano postulat syntezy holistycznego myślenia właściwego kulturze azjatyckiej i analitycznego właściwego kulturze europejskiej ${ }^{16}$. Nieco później przedstawiciele tzw. psychoanalizy kulturowej zauważyli immanentny związek między segmentacją umysłu a niektórymi symptomami chorób, które określamy mianem psychicznych. Sformułowano zasady terapii polegające na zastosowaniu treningu intelektualnego wzorowanego na buddyzmie zen. Holistyczne, płynne myślenie, nastawione na niezakłócony barierami logiki przepływ wrażeń, może być lekarstwem dla umysłów zmęczonych racjonalizmem analitycznym ${ }^{17}$.

Pojawienie się kartezjanizmu było nowym etapem w immanentnym dążeniu ludzkości do okiełznania chaosu poznawczego poprzez ustalenie trwałych prawidłowości, do których można się odwołać, kształtując własne zachowania. Kartezjanizm to racjonalne gromadzenie i użytkowanie wiedzy po to, żeby przetworzyć niepewność na wskazówki postępowania w danej sytuacji. W trakcie ekspansji kartezjanizmu (w epoce XIX-wiecznego pozytywizmu) oczekiwano, że dzięki badaniom i kumulacji wiedzy uda się każdą z dziedzin nauki opisać za pomocą kilku uniwersalnych praw naukowych i dzięki temu wypracować jednoznaczne i bezbłędne wskazówki postępowania, czyli takie, których prawdopodobieństwo sukcesu wynosi jeden. W epoce tej wykrycie prawa uniwersalnego było wstępem do rozciągania go na jak największą liczbę przypadków. W końcu jednak pojawiał się przypadek odmienny, co było interpretowane w kategoriach katastrofy.

Przyczyn upatrywano na ogół w ułomnym stosowaniu danego prawa naukowego lub w błędzie ludzkim. Z czasem nowe badania prowadziły do sformułowania nowego prawa ogólnego, na gruncie którego dawna „katastrofa” dawała się wyjaśnić jako normalne następstwo zjawisk, których wcześniej nie znano i nie opisano. Nadal jednak wskazówki postępowania wyprowadzane z coraz to nowych praw ogólnych traktowano jako pewniki.

W epoce drugiej modernizacji coraz bardziej widoczne było, że pozytywistyczna wiara w to, iż poszczególne dziedziny nauki da się zamknąć w ramach niewielkiej liczby praw ogólnych, okazała się zawodna. Trwa rozwój wiedzy, ale dzieje się to w warunkach jej coraz większego rozdrobnienia.

${ }^{16}$ Zob. M. Scheler, Problemy socjologii wiedzy, przeł. S. Czerniak, E. Nowakowska-Sołtan, M. Skwieciński, A. Węgrzecki, Z. Zwoliński, Wydawnictwo Naukowe PWN, Warszawa 1990.

${ }_{17}$ Zob. np. E. Fromm, D.T. Suzuki, R. De Martino, Buddyzm zen i psychoanaliza, Dom Wydawniczy REBIS, Poznań 2000. 
Kartezjański racjonalizm analityczny upowszechniał się w czasie ekspansji Oświecenia. W Polsce, jakkolwiek miały miejsce zjawiska dalekie od kartezjanizmu, jak walka z napływem „cudzoziemszczyzny i ciasna obrona tożsamości”, mimo wszystko były to, jak pisze Jedlicki ${ }^{18}$, spory w obrębie tego samego kręgu kulturowego.

U nas racjonalność analityczna była wzmacniana poprzez przejmowanie, adaptowanie i kopiowanie różnego typu konstytucji, kodeksów i regulacji prawnych, które zmuszały do zapoznania się z logiką kartezjańską i uczyły opanowania jej pod rygorem niemożności załatwienia codziennych spraw życiowych. I tak np. Kodeks Napoleona, regulując stosunki własnościowe, zmuszał każdego, nawet analfabetę, do opanowania właściwej mu logiki, jeżeli chciał on zrobić cokolwiek ze swoją własnością. Racjonalizm analityczny był upowszechniany także przez instytucje oświatowe, czasami przez literaturę czy niektóre mass media.

Nie przebiegało to oczywiście bez zakłóceń. Ale można mówić o wkomponowywaniu w osobowość zasad racjonalizmu analitycznego, co jest równoznaczne z akulturacją do głównego nurtu filozofii europejskiej i nauk społecznych, a w każdym razie tej ich części, która stanowiła intelektualne zaplecze demokracji i, z różnymi zastrzeżeniami, gospodarki rynkowej.

\section{Bibliografia}

Fromm E., Suzuki D.T., De Martino R., Buddyzm zen i psychoanaliza, Dom Wydawniczy REBIS, Poznań 2000.

Fukuyama F., Zaufanie: kapitał społeczny a droga do dobrobytu, Wydawnictwo Naukowe PWN, Warszawa 1997.

Graff A., Szoruj babciu, „Wysokie Obcasy”, 16.08.2014.

Habermas J., Teoria działania komunikacyjnego, przeł. A.M. Kanowski, t. 1, Wydawnictwo Naukowe PWN, Warszawa 1999.

Hryniewicz J.T., Procesy aktywności publicznej w miejskich społecznościach lokalnych, „Studia Socjologiczne" 1990, nr 3-4.

Hryniewicz J.T., Stosunki w pracy w polskich organizacjach, Wydawnictwo Naukowe Scholar, Warszawa 2007.

Jedlicki J., Jakiej cywilizacji Polacy potrzebują. Studia z dziejów idei i wyobraźni XIX wieku, Wydawnictwo CiS, Warszawa 2002.

18 J. Jedlicki, Jakiej cywilizacji Polacy potrzebują. Studia z dziejów idei i wyobraźni XIX wieku, Wydawnictwo CiS, Warszawa 2002, s. 50 i nast. 
Kartezjusz R.D., Rozprawa o metodzie, Państwowy Instytut Wydawniczy, Warszawa 1980.

Koralewicz J., Wnuk-Lipiński E., Życie rodzinne, towarzyskie i publiczne. Wartości i deprywacje, w: Nierówności i upośledzenia w świadomości społecznej, red. E. Wnuk-Lipiński, IFiS PAN, Warszawa 1987.

Koralewicz J., Ziółkowski M., Mentalność Polaków, Wydawnictwo Nakom, Poznań 1990.

Mirowsky J., Ross C.E., Paranoia and the structure of powerlessness, "American Sociological Review" 1983, Vol. 48, No. 2.

Nonaka I., Takeuchi H., Kreowanie wiedzy w organizacji: jak spótki japońskie dynamizuja procesy innowacyjne, Wydawnictwo Poltext, Warszawa 2000.

Parsons T., The System of Modern Societies, Englewood Cliffs, Prentice Hall, New Jersey 1971.

Porębska M., Suchoń W., Elementarny wykład logiki formalnej z ćwiczeniami komputerowymi, Universitas, Kraków 1999.

Rocznik Demograficzny, Główny Urząd Statystyczny, Warszawa 2012.

Scheler M., Problemy socjologii wiedzy, przeł. S. Czerniak, E. Nowakowska-Sołtan, M. Skwieciński, A. Węgrzecki, Z. Zwoliński, Wydawnictwo Naukowe PWN, Warszawa 1990.

Szmatka J., Źródła i konsekwencje napięć w małych grupach, „Studia Socjologiczne” 1988, nr 3.

Tarkowska E., Mała grupa w nieprzyjaznym środowisku, „Studia Socjologiczne” 1988, nr 4.

Wehler J., Zarys racjonalnego obrazu świata, Oficyna Naukowa, Warszawa 1998. 